\section{Foot-and-mouth Disease}

SiR,-Thank you very much for the leading article on foot-and-mouth disease (23 December, p. 694) and the information contained therein. This will enable some farmers to understand the official precautions to diminish the spread of the present epidemic.

A few points, perhaps inappropriate for a leading article, could with advantage be enlarged upon, as, for example:

As the virus is present in milk, would it not be a gond thing to stop the movement of skim milk immediately an outbreak occurs ?

How long do formaldehyde and sodium hydroxide take to kill the virus ? And, if the virus can survive for three months on gum boots, is the two-second dipping of the lowe part of the boot in dilute phenol (the only readily available antiseptic) of much use ? Similarly, the usefulness of running the $9 \mathrm{ft}$. $(3 \mathrm{~m}$.) periphery of a tractor tyre over $6 \mathrm{ft}$. $(2 \mathrm{~m}$.) of phenol-impregnated straw may be questionable. Undoubtedly these manœuvres pay lip service to a policy of disinfection, as do disinfecting pads on roads at county boundaries, but they can also engender a false sense of security; is their greatest use the reminder that the epidemic exists ?

Has the virus, in fact, ever been isolated from imported meat? And, if so, what is the point of banning imports of such meat only for the duration of the present outbreak? And has the virus been isolated from the feet of migrating birds very frequently, which go on migrating all the time, whether there is foot-and-mouth disease about or not?

Lastly, if the results of vaccination are so unproductive and unrewarding, are the people making vaccine for sale laughing up their sleeves or have they greater belief in its efficacy than your leader writer?

The effect, if any, of the present outbreak on the national economy remains to be seen, but many farmers are faced with the threat or fact of loss of their livelihood and are seeking answers to the foregoing and other questions in highly critical fashion; so, within my own experience, are many veterinary surgeons.-I am, etc.,

Moreton-in-Marsh,

I. A. B. Cathitr.

Gloucestershire.

\section{Lead Poisoning from Eye Cosmetic}

Sir,-Because the source of poisoning in this family, although unusual to us, may prove to be both common and dangerous, we feel that our investigations, albeit incomplets, should be made known promptly.

A 3-year-old Indian boy, resident in England for two years, was admitted to our ward with lead encenhalnpathv. He was semicomatose and developed convulsions in the first twelve hours. Our investigations shrwed haemnglobin $8.3 \mathrm{~g} . / 100 \mathrm{ml}$., with basophilic stippling of red cells ; C.S.F. pressure $225 \mathrm{~mm}$ $\mathrm{Hg}$. and blond lead $178 \mu \mathrm{g} . / 100 \mathrm{ml}$. (Our normal range $0-40 \mu \mathrm{g} . / 100 \mathrm{ml}$.) There were lead lines in the long bones and intestinal opacities on $x$-ray suggesting ingested lead.

The gravity of his illness necessitated evacuation of lead from the bowel, several E.D.T.A. infusions, anticonvulsants, and. later, oral penicillamine. Although now clinically normal his prognosis for mental development is uncertain

An initial investigation of the home by the Greenwich Health Inspector did not reveal any positive clue. The family had only recently moved into the area and it was considered that the source was probably in their previous home, 16 miles away. Screening the family, we found mother and a sibling aged 5 years had blood leads of $65 \mu \mathrm{g} . / 100 \mathrm{ml}$. and $72 \mu \mathrm{g} . / 100$ $\mathrm{ml}$. respectively, but no overt evidence of lead poisoning. The father and the three older sibs (all at school) had blond lead levels of 10 $\mu \mathrm{g} . / 100 \mathrm{ml}$. or less. After two weeks at home and although he had been discharged on ora penicillamine $150 \mathrm{mg}$. b.d., the patient's blood lead had risen from $10 \mu \mathrm{g} . / 100 \mathrm{ml}$. to $84 \mu \mathrm{g}$./ $100 \mathrm{ml}$. and there were scanty radiologica opacities in the lower bowel suggesting further ingestion of lead.

One of us (M.A.W.), a Hindi-speaking senior house officer, and a health visitor started another investigation of the home. Two aspects of the problem worried us, (a) that the source was in the house, and (b) that the three affected members were exposed to the same agent.

Investigations of the house-paintwork water supply, cooking utensils, food, etc.still revealed nothing significant. The only factor common to the three affected members was a mascara-like substance applied to their eyelids and conjunctivae, in the mother's case for cosmetic reasons and in the children's for " health." A sample of the powder analysed by the local authority (Greenwich Public Health Department) showed that the powder contained $80 \%$ lead sulphide. It was easily accessible to the small children and it is not unlikely that our patient, in addition to lead absorption from the skin, ${ }^{2}$ also took some lead orally, as there was radiological evidence on two occasions of opacities in the gut.

We deleaded all three of them and our patient is still on oral penicillamine. The mother, who was then 36 weeks pregnant, has recently had a normal infant. The cord blood lead level is not yet known. Samples of a powder used for the same purpose have been collected from Indian and Pakistan immigrant patients, a laboratory technician, and an Indian grocer. Analysis in our laboratory showed them to have lead sulnhide contents ranging from $66 \%$ to $88 \%$. These powders originated from India, mainly the north, and Pakistan. Interviews with Indian colleagues and friends revealed that some Indians and Pakistanis use a home-made carbon paste instead.

There are approximately 323,000 Indians and Pakistanis in the United Kingdom. Even if only a percentage of them use this easily available lead compound, the implications are not only enormous but very serious.-We are, etc.,

Brook General Hospital, P. O'GormaN.

\section{A. WARLEY.}

London S.E.18.

REPERENCES

Perlstein, M. A., and Attala, R., Clin. Paediat. $1966,5,292$.

Mirando, E. H., and Gomez, M., Arch. Dis. Childh., 1967, 42.579.

\section{Statistics on Blindness}

SIR,-Blind statistics in 1958 and $1962^{1}$ caused official perturbation $(80 \%$ of persons registered as blind from cataract and $40 \%$ from glaucoma have had no treatment), and in $1966^{2}$ jubilation (Britain is beginning to win the battle against blindness, Britain's blind population is not increasing, major credit is given to the N.H.S.), and now' the
Minister announces in Parliament that, "Fewer of our old people are going blind, simply because under our system they can be diagnosed and treated for cataract in time."

The three main causes of blindness in old people are macular degeneration, cataract, and glaucoma. What are the ascertainable statistics? In the last three years the total number of persons on the blind register and the number of new registrations, both previously near stable, increased by $5 \%$ and $15 \%$ respectively. Similarly, the increases on the partial sight register were $18 \%$ and $22 \%$. As regards cataract alone, Professor Sorsby ${ }^{4}$ has shown that between 1949 and 1960 the number of new registrations fell by $23 \%$; subsequent statistics for persons over the age of 64 years have not been published.

Thus, as regards registered blindness due to cataract, credit must be given to the N.H.S. up to 1960 . As regards glaucoma, no credit can be given for the delay in introducing measures to detect the disease in an early stage, ${ }^{s}$ and as regards macular degeneration neither credit nor discredit is applicable. But, as Professor Sorsby points out, blind statistics depend on social rather than ophthalmological factors, and the number registered annually represents only a portion of a larger-and perhaps a very much largernumber. Thus "registered blind" is not synonymous with "blind population," and changes in the former cannot be relied upon to reflect changes in the latter, except in a static society. It is ridiculous that each year we record the number of cases of ophthalmia neonatorum (no longer a cause of blindness), the number of glass eyes dispensed, and even the number of spare parts for invalid carriages, yet in a Welfare State we cannot know the prevalence, or, what is more important, the incidence, of blindness. In view of the importance of blindness in old people it is high time that Parliament and the profession had statistics which are both realistic and up to date. Surely the introduction of compulsory notification would be a credit to our system.-I am, etc.,

Tonbridge,

Kent.

P. Richard Day.

RBPERENCES

Standing Medical Advisory Committee for the Central Health Services Council and the Minister of Health. The Prerention and Alleviazion of Blindness, 1962 Ministry of Health, London. The Times. 24 February 19n6

Hansard, 755, No. 28, 7 December 1967, Col. 1679.

Sorehy A., Ministry of Health Report on Public Health and Medical Subjects No. 114. Th Incidence and Causes of Blindness in England
and Wales, 1948-1962, 1966 . H.M.S.O., London.

Brit. med. 7., 1963, 1, 624.

SIR,-I was interested to note the correspondence concerning headlight glare by $\mathrm{Dr}$. S. J. Lines (30 September, p. 867) and Professor A. E. Mourant (14 October, p. 113). The solutions proposed are most interesting, but I would suggest that it would be even more difficult to get the driving public to accept Polaroid spectacles than it is to ensure the use of safety belts.

Having recently returned from a year spent in Britain, where I had to do much driving after dark, I would propose that the best way of avoiding accidents at night is to make it compulsory to have all headights turned on after dusk, even in street-lighted areas. In 